\section{Cattle killer}

\section{Len Goodwin}

Science and Empire: East Coast Fever in Rhodesia and the Transvaal. By Paul F. Cranefield. Cambridge University Press: 1991. Pp.385. £45, \$65.

EAST coast fever is caused by Theileria parva, a minute tick-borne parasite that enters the T lymphocytes and stimulates them to divide indefinitely, like a lymphoblastic neoplasm. The parasites associate themselves with the Golgi apparatus and divide and multiply with the cells. Some, in the form of minute bars and curved rods, are found in the erythrocytes and infect the brown tick, Rhipicephalus appendiculatus, when it feeds. The disease can kill 95 per cent of a herd of cattle in three weeks; it is still the subject of active research and there is as yet no practical method of immunization and no effective treatment.

In 1896, the rinderpest virus swept through southern Africa and killed nearly all the cattle. Less than six years later, after the Boer war and the slow and costly replacement of the animals another, almost invariably fatal disease, African coast fever, broke out in Rhodesia. The infection probably came in an animal or a tick that had travelled by land or sea from Dar es Salaam to Umtali on the Mozambique border. It was at first thought to be a virulent form of the well known 'redwater', caused by Babesia bigemina, and to which tolerance develops. But it spread very rapidly, notably through the transport riders, whose huge ox wagons became "abandoned in the veld, abandoned beside the bones of their dead oxen". Confusion was inevitable in a country with two sources of authority that distrusted each other (the South Africa Company and the Colonial Office) and a settler population demanding more and more self government. Rhodes had just died, and for the Chartered Company "to admit the existence of a new cattle disease would have sent down Rhodesian shares".

After months of delay, at a fee with a present-day value of $£ 200,000$, the company appointed the famous German bacteriologist, Robert Koch, to advise. Koch had already seen the disease in German East Africa in 1897 and had described the dividing forms of the parasite (Koch's blue bodies) in the lymph nodes. But he had decided that it was a severe form of redwater, carried by the blue tick, $R$. decoloratus and that the small bacillus-like rods he saw in the red cells were immature forms of the redwater parasite. In Bulawayo he realized that it was a new, different disease, characterized not by haematuria, but by anaemia, lymphatic involvement and pulmonary oedema. Although he was unable to transmit the infection by blood inoculation, he thought that he had succeeded in making a protective serum. This subsequently proved to be useless.

Clarification came from Arnold Theiler, a Swiss veterinarian and Charles Lounsbury, an American entomologist, of the Department of Agriculture of the Transvaal. Theiler showed that the small rods in the red cells were responsible, and Lounsbury proved that the brown, not the blue tick was the vector. Preventive measures were difficult to enforce - the farmers were too poor to accept a slaughter policy - and it took 50 years to bring the disease under control. Although Koch was too self-confident and the Rhodesian veterinarians, Gray and Robertson, were wrong to discount the possibility of a new disease, they deserve some sympathy. Redwater and east coast fever frequently occurred in the same animal, and the very small dots and dashes they peered at, near the limit of resolution of the microscopes of the time, in fact represented four different parasites - redwater (Babesia), gall sickness (Anaplasma) and two species of Theileria, parva and mutans, sometimes all together in the same erythrocyte.

A key figure behind the scenes was the British Colonial Secretary, Joseph
Chamberlain, who had a deep interest in science and a belief in empire. He was involved in the growing conflict between British and German colonial ambitions in Africa and he resented the appointment of Koch as a consultant. He was convinced that the relief of poverty in Britain depended on the expansion of trade with the colonies and that medicine and science had a crucial role to play. He fostered Kew Gardens, he created the London School of Tropical Medicine and the Royal Society's Malaria an' Tsetse Fly Committees, and he believed that civil servants in government should rely upon the scientific advice of experts. We could do with him today.

Paul Cranefield's method of dealing with the story from the points of view of all the players involved - administrators, politicians, veterinarians, farmers, Africans, cattle, ticks and parasites - makes for a good deal of repetition. But he has tracked down all the documents, from the Colonial Office to the Bulawayo Club, and provides nearly 100 pages of useful notes, comments and references.

Len Goodwin is at Shepperlands Farm, Park Lane, Finchamstead, Berkshire RG11 4QF, UK.

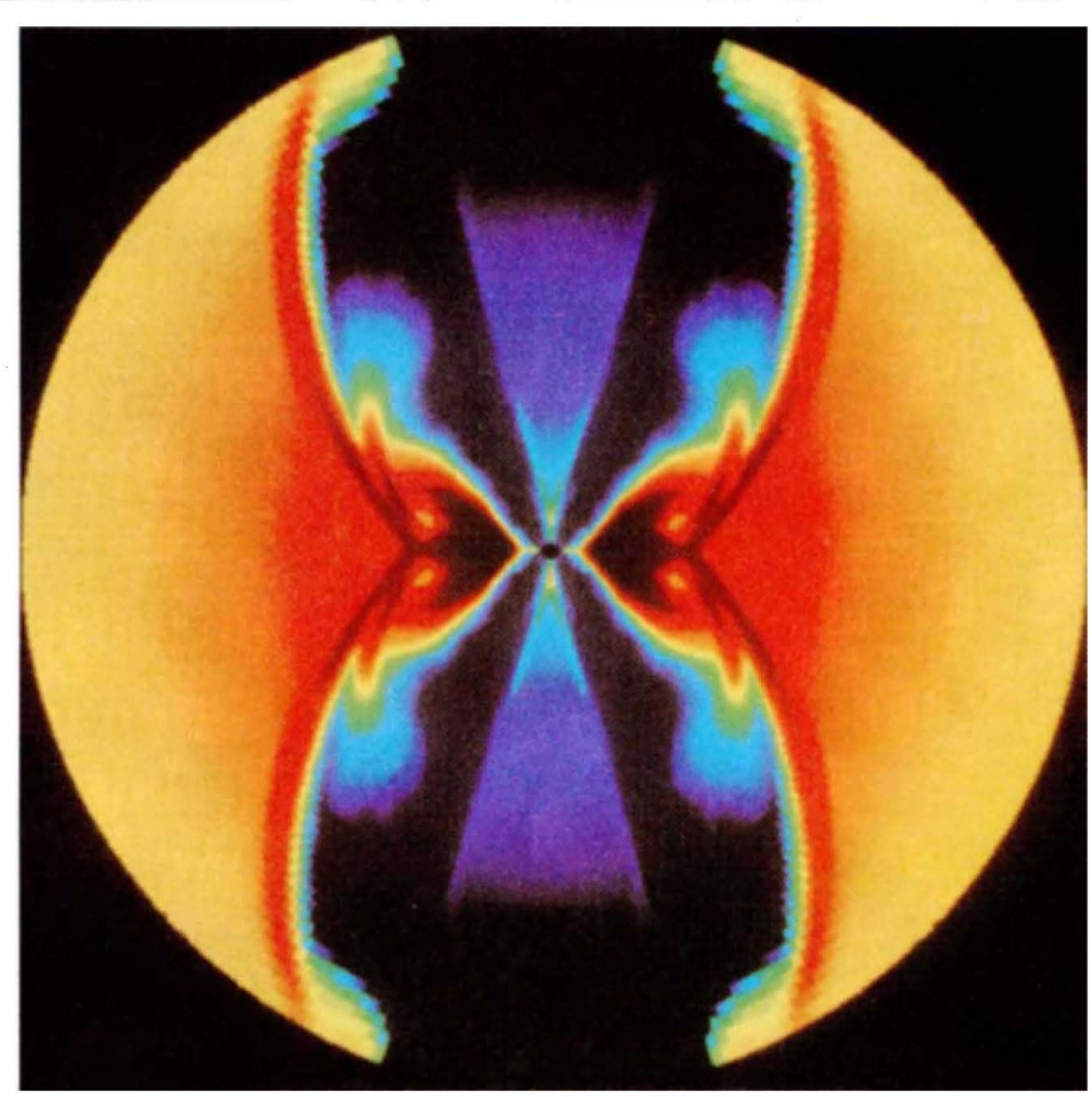

Computer simulation of a black hole. The spectacular photograph reproduced above represents the output of an extraordinary computer simulation in which $1.28 \times 10^{9}$ data points were calculated. The visualization shows the way in which a new supply of low-density matter falls into the dense core of a black hole once the matter in its immediate vicinity has been consumed. The picture comes from Visualization: The Second Computer Revolution by Richard Mark Friedhoff, a lavishly illustrated guide to computer graphics and its applications. Published by Freeman; price $\$ 24.95$ (pbk). 